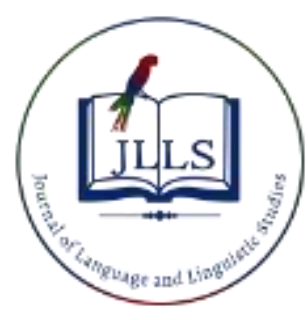

Available online at www.jlls.org

JOURNAL OF LANGUAGE

AND LINGUISTIC STUDIES

ISSN: 1305-578X

Journal of Language and Linguistic Studies, 16(2), 775-797; 2020

\title{
A systematic review on flipped learning in teaching English as a foreign or second language
}

\author{
Abdullah Arslan a 1 (iD) \\ APA Citation: \\ ${ }^{a}$ Shanghai International Studies University, Shanghai, China \\ Arslan, A. (2020). A systematic review on flipped learning in teaching English as a foreign or second language. Journal of Language and \\ Linguistic Studies, 16(2), 775-797. \\ Submission Date:08/01/2020 \\ Acceptance Date:07/03/2020
}

\begin{abstract}
The aim of this study was to discuss benefits and challenges of flipped learning in teaching English as a foreign or second language through a systematic review. Prior to conducting this systematic review, 78 studies published in journals that are indexed in Web of Science (WOS), ERIC, ScienceDirect, SCOPUS, IGI Global, and Wiley Online Library databases were selected in accordance with a set of inclusion and exclusion criteria. As a result of the coding process, themes and sub-themes emerged based on the content analysis. The findings reveal that there is an increase in the publications on the implementation of flipped learning in teaching English as a foreign or second language. It is also seen that the majority of the studies about the implementation of flipped language learning includes university students as participants. One of the most reported benefits of the use of flipped learning in this field is that it has positive effects on enhancing students' English language skills such as writing and speaking. In some of the reviewed studies, however, some issues like access to the Internet and workload for both students and teachers are among the most expressed challenges.
\end{abstract}

(C) 2020 JLLS and the Authors - Published by JLLS.

Keywords: teaching English; language learning; language skills; flipped learning; blended learning; content analysis

\section{Introduction}

With the emerging notion of employing technology tools to assist high school students in their courses, flipped learning as contemporary instructional design which is coined by Bergmann and Sams in 2007 (2012) basically aims to reverse the order of classroom activities in the sense that what students usually do at home is fulfilled in classroom and vice versa (Bergmann \& Sams, 2012). Flipped learning is generally defined as an instructional method in which homework and input material are completed by students before the class in order to devote more in-class time to discussions, projects, and other forms of meaningful interactions (Gasmi \& Thomas, 2017; Li \& Zhang, 2016; Tohei, 2018). It is also

\footnotetext{
${ }^{1}$ Corresponding author. Tel.: +86-186-213-796-73

E-mail address:w1926@ shisu.edu.cn
} 
conceived of as a kind of blended learning by some researchers (Abeysekera \& Dawson, 2015; Diaz \& Brown, 2010; Picciano et al., 2014; Strayer, 2012).

Learning in flipped classroom is self-paced and allows students to access learning activities at their own convenience based on the flexibility of "anywhere, anytime" (Cottrell \& Robison, 2003; Yu \& Zhu, 2016). Flipped learning offers students the chance to be able to collaborate in classroom to increase engagement level and improve comprehension and retention (Perkins, 2006; Roberts \& Plakhotnik, 2009). In addition to this, flipped learning frees up class time for students to become more inclined to engage in interactive and intellectually challenging learning tasks and activities. In the literature, however, some researchers have drawn attention to limitations of flipped learning. For instance, Missildine et al. (2013) warn that implementation of this instructional approach in those settings where students do not have equal access to technology may be counterproductive. Additionally, Hamdan et al. (2013) argue that conservative educational cultures may find embracing flipped learning challenging, hence an adjustment to both learning and teaching methods may be required to derive complete benefit from it. Similarly, Strayer (2012) states that students' faith in flipped learning plays a very crucial role in doing more work both in and out of the classroom. Another issue being discussed is the supplementary training of teachers prior to implementing flipped learning in order to expose students to self-paced interactive learning environment instead of the traditional education environment where content is overly laid emphasis (Kim et al., 2014). Besides, Nielsen (2012) expresses that the dearth of readily available activities and instructional resources increases teachers' workload for the preparation of those kinds of materials.

\subsection{Literature review}

As an educational method with the assumption of exchanging the order of homework and instruction, flipped learning has gained great attention of many researchers (LaFee, 2013; Sams \& Bergmann, 2013) since 2012. Much has been published related to the use of flipped learning especially in the fields of STEM education since the pioneers of flipped learning initiate the use of the approach in chemistry class with a view to assisting students in compensating for the missing classes (Bergmann \& Sams, 2012). After its implementation in chemistry class, the teachers observe students' excitement and motivation in flipped learning activities. They also note that this type of learning is more efficient than lecturing and assigning homework in teaching chemistry (Sams \& Bergmann, 2013). Likewise, Coyle et al. (2017) infer that online materials and activities regarding calculations and sketches in a STEM course promote development of the skills of communication and collaboration, thereby increasing their knowledge retention. In another STEM research (Ogden \& Shambaugh, 2016), the researchers state that flipped learning increases students' satisfaction especially with the video lectures about algebra and provides students with the affordance of reaching them anytime anywhere. Trogden also (2017) underlines that students favour flipped organic chemistry activities instead of lecture-based classroom activities in which they have no enough chance of asking questions at that very moment. Another study (Cresap, 2017) concludes that in-class discussions and activities result in more questions from more students and higher success in-class quizzes after the order of a traditional course is flipped in a MIS course (Management Information Systems). In the same way, Umezawa et al. (2017) indicate that doing selfstudy with activities can raise students' level of understanding of the content, making them to be active participants of learning process in a flipped course. Amhag (2017) holds the same view that flipped videos are likely to support active learning and collaboration among students, allowing them to review knowledge critically in a more learner-centred manner. Many scholars hold the view that (Chellapan \& Meer, 2017; Dennen \& Spector, 2017; Plaisent et al., 2017) implementing flipped learning in teacher education requires teachers to ponder how flipped learning could be folded into the existing curricula of 
educational technology courses. They assume that when necessary adjustments are done in conformity with flipped learning, learning experience could be truly positive, engaging and enjoyable for students.

A number of studies have investigated the effectiveness of flipped learning in the field of teaching English as foreign or second language (hereafter EFL/ESL). The researchers (Al-Harbi \& Alshumaimeri, 2016; Thaichay \& Sitthitikul, 2016; Webb \& Doman, 2016) who explore the effectiveness of flipped English grammar courses, come to the conclusion that flipped learning plays an important role in enhancing students' grammar performances, making them more comfortable and confident about using English grammar. Similarly, flipping a writing course brings about better academic achievements in writing and increases students' level of engagement in writing process (Afrilyasanti et al., 2017; Gasmi \& Thomas, 2017; Zhonggen \& Guifang, 2016). As for a flipped speaking course, flipped learning not only helps students improve their oral skills in English but also it enables them to be autonomous learners in order to have a deeper understanding of the course content (Choe \& Seong, 2016; Li, 2016; Li \& Zhang, 2016; Xin-Yue, 2016). Several studies have explored the effects of flipped learning on language students and concluded that it motivates students to use English idioms and vocabulary more effectively for communication interaction. The results of the studies substantiate that flipped learning encourages students to study at their own pace by taking responsibility for their own learning (Chen et al., 2017; Çelebi et al., 2016; Hung, 2015; Yang, 2017).

At the time of undertaking this systematic review study, only a limited number of studies have touched on the use of flipped learning in various disciplines from different perspectives. To illustrate, a scoping review study examining the use of flipped learning in higher education (O'Flaherty \& Phillips, 2015) highlights that flipped learning can be an opportunity for teachers and academics to renew their existing curricula. A cohort of review studies reports that the use of flipped learning (Chen et al., 2017; Lo \& Hew, 2017; Presti, 2016) may be effective in promoting active learning and increasing students' motivation and engagement level. Evidence from several cohort review studies indicates flipped learning generally encompasses research and studies that started in 2011 in the field of STEM (i.e. science, technology, engineering, and mathematics) and in some other disciplines. It is also revealed that countries that have most publications on flipped learning are USA, Malaysia, Jamaica, Hong Kong, Singapore, Somaliland, China, Taiwan, Australia, Canada, Saudi Arabia, and Turkey (Karabulut-Ilgu et al., 2018; Lo \& Hew, 2017; Uzunboylu \& Karagözlü, 2017; Yang et al., 2017). There is a notable scarcity of literature from Europe (O’Flaherty \& Phillips, 2015; Uzunboylu \& Karagözlü, 2017).

\subsection{Research questions}

Although there is a plethora of studies, a few of which are review studies on the use of flipped learning in the fields of science, technology, engineering and mathematics, and nursing, there is a paucity of review studies that explore the use of flipped learning in the field of teaching EFL/ESL. Hence, this research is possibly an initial step towards a more profound understanding of the benefits and challenges of flipped learning in this field through a systematic review.

A systematic review is a laborious and thorough process starting from the exploration of published literature to conducting an analysis concerning a myriad of collected references over a specific topic (Chen et al., 2016; Hart, 1998; Gash, 2000; Grewal et al., 2016; Ridley, 2012). This type of review may also enable policymakers and other stakeholders to acquire clear and brief reference (Akçayır \& Akçayır, 2017; Galvez, 2017) in their quest for making vital decisions with regard to the implementation of an innovative pedagogy like flipped learning through aggregation, interpretation, explanation, or integration of the existing research (Rousseau et al., 2008; Xiao \& Watson, 2017). It is hoped that this study will lead to new insights for policymakers, curriculum designers, teachers as well as researchers 
who are planning to make investments in flipped learning soon. Accordingly, the following objectives have been pursued throughout the duration of the research:

RQ1. What is the distribution of reviewed studies by year in the field of teaching EFL/ESL since $2012 ?$

RQ2. What is the profile of students in the reviewed studies in the field of teaching EFL/ESL?

RQ3. What benefits of flipping learning in the field of teaching EFL/ESL are presented in the reviewed studies?

RQ4. What challenges of flipping learning in the field of teaching EFL/ESL are presented in the reviewed studies?

\section{Method}

\subsection{Process of Manuscript Selection}

A systematic review, by definition, is a type of literature review seeking to identify all the available evidence on a topic to reduce the effect of bias on the review findings (Booth \& Papaioannou, 2016). In social sciences, a literature review including grey literature may also be a necessity since it serves huge quantity of evidence (Grayson \& Gomersall, 2003; Young et al., 2002). In a systematic review, it is imperative to include as many studies as possible by searching beyond academic literature alone (Hartling et al., 2017). The underlying rationale for adding the grey literature to this systematic review study is merely an attempt to reduce the impact of publication bias (McAuley et al., 2000). To identify potentially relevant studies, Web of Science (WOS), ERIC, ScienceDirect, SCOPUS, IGI Global, and Wiley Online Library databases were initially searched since they are regarded as major databases for the social sciences (Taylor et al., 2003). Then, ProQuest and Google Scholar as the sources of grey literature were searched in order to reach more publications that are not frequently indexed within traditional databases (Gough et al., 2017; Littell et al.,2008; Petticrew \& Roberts, 2006; Xiao \& Watson, 2017).

Table 1. Inclusion and exclusion criteria

\begin{tabular}{ll}
\hline Inclusion criteria & Exclusion criteria \\
\hline $\begin{array}{l}\text { a. Flipped language learning must be the } \\
\text { focal point of a study }\end{array}$ & $\begin{array}{l}\text { a. Editorials are excluded. } \\
\text { b. A full-text conference paper }\end{array}$ \\
\begin{tabular}{ll} 
c. A complete report disseminated by any & c. Studies in other languages \\
institution & \\
d. A complete dissertation & \\
\hline
\end{tabular}
\end{tabular}

The selection of studies for the current study was made according to a set of inclusion and exclusion criteria (Table 1). Web of Science with the largest indexed journals was the initial step for the researcher to look into publications on flipped learning in the field of EFL/ESL In order to identify as much research concerning flipped learning in teaching EFL/ESL as possible, in each search string Boolean "AND" (Gough et al., 2017) was employed between the keywords. The search results yielded 167 studies from the databases (Figure 1). Upon removing the duplicates, there were 130 studies to be reviewed. After the examination of the titles and abstracts, 25 of those studies were removed since they were not relevant to EFL/ESL teaching context. Since two of them were written in other languages, and two of them were incomplete studies, they were also excluded from this study. The remaining studies were reviewed for 
eligibility and the results showed that the focal point of 17 studies were not basically teaching/learning EFL/ESL, and 10 of them did not have content related to EFL/ESL, thus they were excluded from the study. As a result of reviewing studies for eligibility, there finally remained a total of 78 studies to be reviewed.

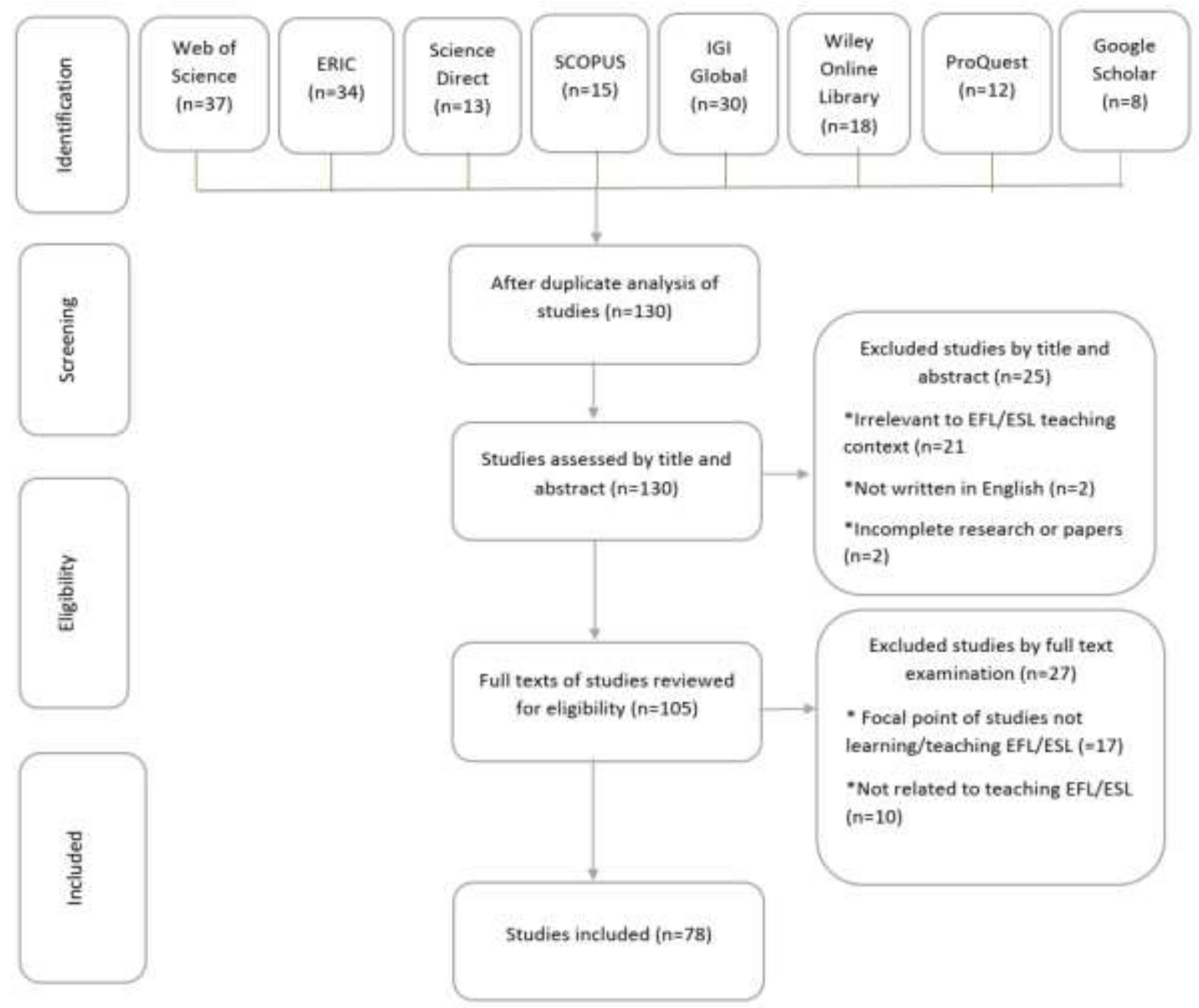

Figure 1. Flow of systematic review process (adapted from Moher et al., 2010).

\subsection{Data Coding and Analysis Processes}

Content analysis is defined as a research method for making replicable and valid inferences from verbal, visual, or written data with the intent of both depicting and quantifying specific phenomena (Downe-Wambolt, 1992; Krippendorff, 2004). Through the content analysis, data were presented in words and themes to draw some interpretation based on the results of reviewed studies. Within the framework of qualitative content analysis, latent analysis was carried out at interpretive level where the researchers sought to identify underlying meaning of texts in the studies (Berg \& Lune, 2001; DowneWambolt, 1992). For the first research question, the year of a study referring to its publication time was taken into consideration and identified by the researcher. As for the second research question, the researcher classified the profile of participants into three groups: gender, education level, and location.

For the third and fourth research questions addressing the benefits and challenges of flipped learning in the field of teaching EFL/ESL, the four stages as decontextualisation, recontextualisation, categorisation, and compilation were followed in conducting content analysis of the data. In order to maintain the quality and trustworthiness of the analysis, each stage was independently performed several times in collaboration with an external coder having insight into qualitative data analysis. To increase 
the validity of the current study, the analysis was separately conducted and the results were discussed to reach an agreement on the themes and sub-themes (Burnard, 1991; Graneheim \& Lundman, 2004). The researchers familiarised themselves with the collected data to obtain the sense of the whole. Before starting analysis process, the deductively generated coding list was employed to obtain high reliability (Catanzaro, 1988). While analysing the data, each identified meaning unit was labelled with a code related to the context. The data were re-read alongside the final list of meaning units after the identification of meaning unit within the data. In line with the meaning units gathered by the researchers, themes and sub-themes were identified and then established as a result of each coder's final coding process (Burnard, 1991; Graneheim \& Lundman, 2004). The inter-coder reliability was found to be .89 . Finally, the themes and sub-themes were presented in tables.

\section{Results}

\subsection{Distribution of the published studies in time}

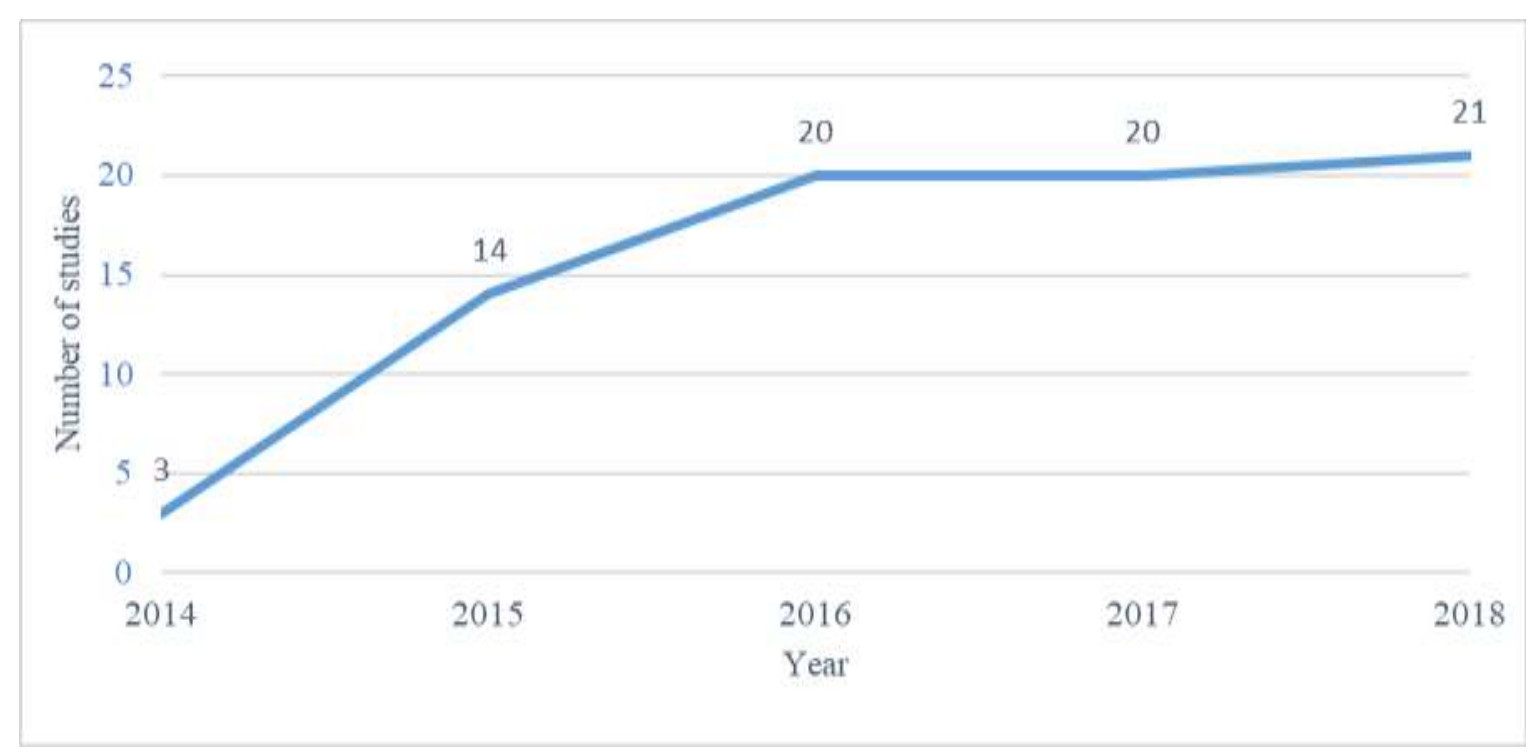

Figure 2. Number of studies published by year

The number of studies starting in 2014 has been constantly on the increase since the publication of a seminal work, Flip your classroom: Reach Every Student in Every Class Every Day (Bergman \& Sams, 2012) in 2012. In addition to the use of flipped learning in STEM fields, flipped learning has started to gain popularity since 2012 (Figure 2). Flipped learning has also begun to flourish in the field of teaching EFL/ESL together with societal and educational tendencies towards more frequent and common use of technology. Though cell phones are initially used for verbal communication, they have started to evolve into smart devices for users to text, access the Internet, listen to music, play games and lots of other activities (Rideout, Foehr, \& Roberts, 2010) In a report on smartphone adoption among American teens indicates that the number of teens having cell phones increases substantially and mobile access to the Internet becomes pervasive. It is also stated that $74 \%$ of teens in the U.S. have access to a cell phone, and 93\% have computer access at home (Madden et al., 2013). It is also underlined that teens represent the leading edge of mobile connectivity, and increasingly these phones are affording teens always-on, mobile access to the internet - in some cases, serving as their primary point of access. A recent study (Ross, 2011) stresses that $87 \%$ of students consider technology as an important factor in their decision 
to attend school. Moreover, according to another study conducted by Russell (2012), there are over five million students attending at least one hybrid or online course in the U.S.

Technology is an integral part of life in the 21 st century with its continued proliferation of digital technologies and gadgets available to people in recent times. With the ease of technology, it has become easier for people to connect with each other in the realm of knowledge sharing. Hence, the push for more technology integration in schools continues since those technologies and gadgets undoubtedly provide new opportunities and spaces for those who are looking for new ways of presenting knowledge through the use of technology integrated with learning approaches such as flipped learning (Katz \& Kim, 2017; Lee, 2017; Salifu, 2016; Shaffer, 2017; Snyder, 2017; Wells \& Holland, 2017). At this point, it may be assumed that the proliferation of digital technologies and gadgets in recent years have paved schools and educators in the field of EFL/ESL for seeking more creative ways to integrate existing teaching and learning approaches into digitally-enriched environments where students may engage with peers actively in constructing knowledge. Hence, the increase in the number of publications might be attributed to the recent developments in technology and proliferation of digital technologies around the world. The increase in the number of studies in time also shows that teachers and schools are trying to keep up with these developments by trying to adopt flipped learning to their existing curricula and courses (Figure 2). Taken the roots of flipped learning in chemistry in the early-mid 2000s into consideration (Bergmann \& Sams, 2012), flipped learning has taken some time to grow in popularity in the field of teaching EFL/ESL.

Meanwhile, it should be borne in mind that for the last few decades, internet-based technologies and education technology have transformed and taken various forms such as online courses, hybrid courses, blogging, and the flipped (or inverted) classroom, which are considered as a couple of those innovations (Dennen \& Spector, 2016; Prodoehl, 2015). Flipped learning has taken root and gained momentum across all levels of education since 2007. Growth in interest in flipped learning has continued in the meantime (Bergmann \& Sams, 2012; Cresap, 2017; Faulkner \& Green, 2017) and the pedagogy of flipped learning is becoming increasingly widespread around the world (Bergmann \& Sams, 2012; Parslow, 2012; Trogden, 2017).

There has been an exponential increase in the numbers of studies in teaching EFL/ESL context since 2015, which might be associated with the increase in publications and interest in flipped learning from 2012 onwards (Bergmann \& Sams, 2012; Yarbro, et al. 2014). In addition, the number of studies concerning the use of flipped learning in the field of teaching EFL/ESL has escalated in the last three years (Figure 1). This could be associated with the notion that there is a need or quest for a dramatic shift from lecture-centred instruction to student-centred instruction (Katz \& Kim, 2017) since in traditional teaching where the teacher is the main source of information may not meet the needs of students who are deeply interested in mobile technologies such as laptops, tablets, or smart phones (Amhag, 2017).

At this point, flipped learning with the support of dynamic, interactive, social, and adaptive technologies (Bergmann \& Sams, 2012; Brown, 2012) has come to the fore to provide opportunities and space for students in learning English by repurposing and allocating class time for active learning (Moran et al., 2017). Flipped learning has also offered some incentive for all interested in education to renew their existing curricula and curricular activities. This is obviously understood by the statistical information provided by Flipped Learning Network. According to the statistical information of FLN, the term "flipped learning" was searched 244,000 times and "flipped classroom" was searched 1,690,000 times in Google in June 2014 (Yarbro et al., 2014). This also implies that the employment of flipped learning in teaching EFL/ESL is likely to continue in the coming years and more research is likely to be carried out in this field. 


\subsection{Profile of participants in the reviewed studies}

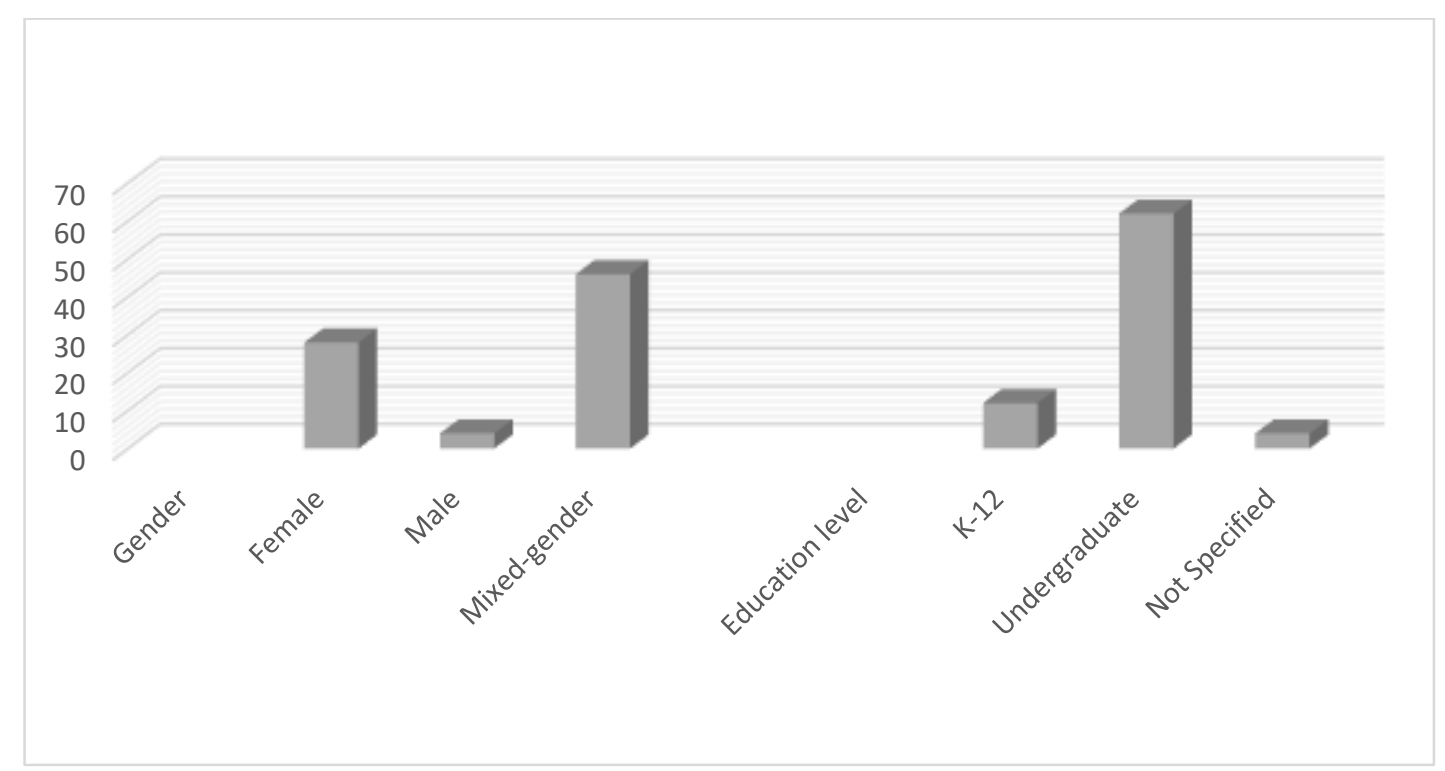

Figure 3. Gender and education level of participants

Figure 3 reveals that in the vast majority of the studies (80\%) undergraduate students are selected as the sample, followed by K-12 students (15\%), and remaining studies (5\%) include adults attending EFL teaching education programs with various backgrounds.

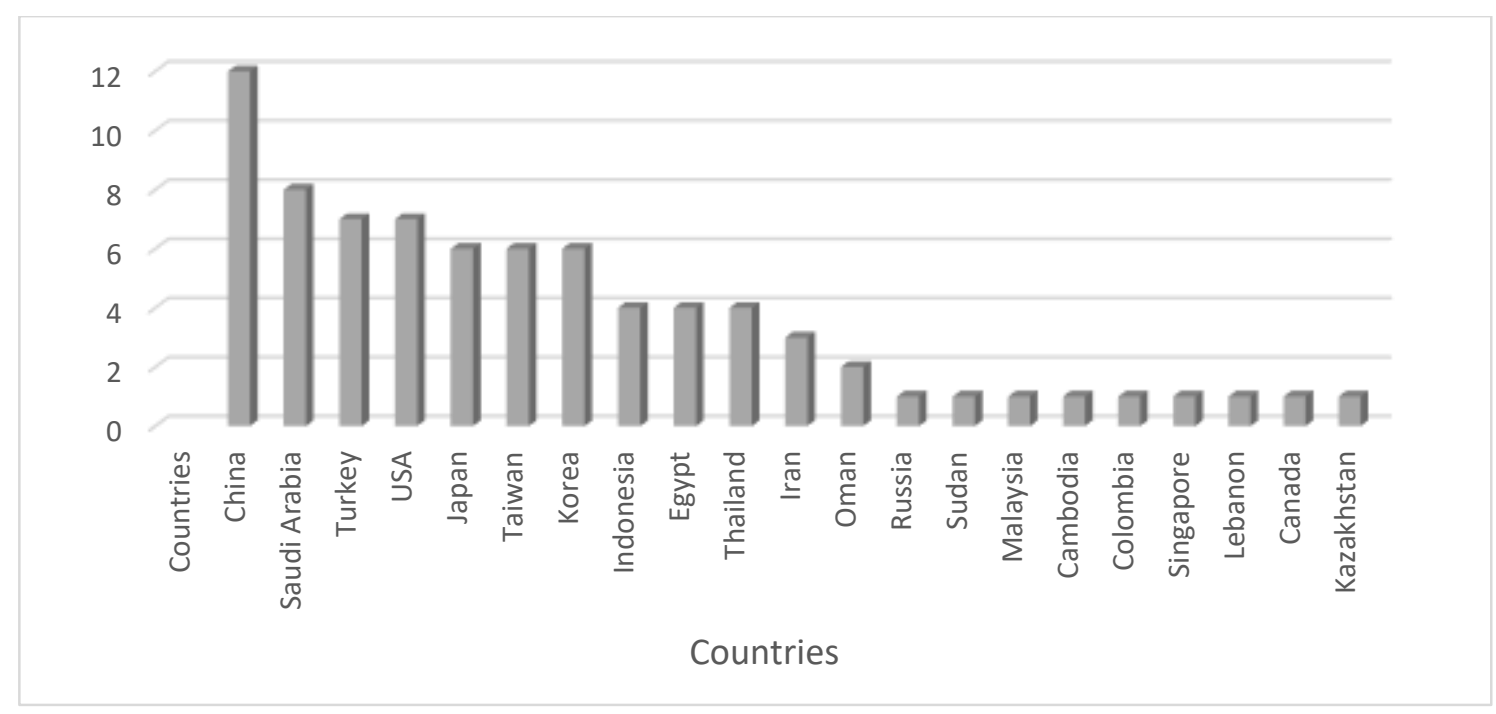

Figure 4. Countries of participants in the reviewed studies

The participants are located in different parts of the world, mostly in China $(n=12)$, Saudi Arabia $(\mathrm{n}=8)$, Turkey (=7), USA ( $\mathrm{n}=7)$, Japan ( $\mathrm{n}=6)$, Taiwan (6), and Korea (6) in the reviewed studies. The implementation of flipped learning in the field of teaching EFL/ESL is quite widespread around the world (Figure 4). 


\subsection{Benefits of flipped learning}

As a result of coding process of the data, identified benefits of flipped learning in the field of teaching EFL/ESL were arranged into three categories such as student gains, pedagogical contributions, and interaction (Table 2).

Table 2. The benefits of flipped learning in teaching EFL/ESL

\begin{tabular}{llcl}
\hline Categories & Sub-categories & $\mathrm{f}$ & Sample Research \\
\hline Student gains & Improves language skills & 41 & Abaeian \& Samadi, 2016 \\
& Increases motivation & 35 & Adnan, 2017 \\
& Encourages students to be more active & 28 & Ahmad, 2016 \\
& Provides positive attitude & 23 & Amiryousefi, 2017 \\
& Builds self-confidence & 10 & Engin \& Donanci, 2016 \\
& Takes on responsibility for learning & 9 & Ekmekci, 2017 \\
& Increases satisfaction & 7 & Hsieh et al., 2017 \\
& Improves cognitive strategies & 3 & Sun, 2017 \\
Pedagogical & Increases engagement level & 19 & Yang, 2017 \\
& Provides self-paced learning & 18 & Köroğlu \& Çakır, 2017 \\
& Provides immediate feedback & 17 & Choe \& Seong, 2016 \\
& Provides collaboration opportunities & 14 & Gasmi, 2016 \\
& Enables meaningful learning & 11 & Wu et al., 2017 \\
& Enables teacher to be a facilitator & 8 & Sun, 2017 \\
& Creates flexible learning environment & 5 & Hung, 2017 \\
& Enhances personalized learning chances & 5 & Li, 2016 \\
& Enhances enjoyment & 5 & Doman \& Webb, 2017 \\
& Provides interaction opportunities & 41 & Zainuddin, 2017 \\
& (student-student) & & \\
& Student-teacher & 27 & Karimi \& Hamzavi, 2017 \\
& Student-material & 7 & Zhonggen \& Guifang, 2016 \\
\hline
\end{tabular}

Over half of the studies discuss that the use of flipped learning in the field of teaching EFL/ESL is conducive to improving language skills of students. Quite a few studies point out that the employment of flipped learning plays an important role in the improvement of language skills of students, namely vocabulary, writing, listening, reading, and speaking skills (Abdelrahman et al., 2017; Ahmad, 2016; Al-Ghamdi \& Al-Bargi, 2017; Buitrago \& Díaz, 2018; Chen Hsieh et al.,2017; Grimsley, 2015; Karimi \& Hamzavi, 2017; Li, 2016; Li \& Zhang, 2016; Loucky, 2017a; Kirk \& Casenove, 2017; Roth, 2016; Iyitoğlu \& Erişen, 2017; Suranakkharin, 2017; Xie \& Fang, 2016; Zhang, 2015; Zhang et al., 2016). A study performed by Abaeian and Samadi (2016) underlines that the use of flipped learning in the field of teaching EFL/ESL results in the improvement of students' reading comprehension ability. Since flipped learning encourages students to be more active in performing activities through collaboration, interaction, and discussion (Abdelshaheed, 2017; Afrilyasanti et al., 2017; Ahmad, 2016; Brown, 2017; Li \& Zhang, 2016; Rosen et al., 2017; Teng, 2018; Zhang, 2015), they have the enough opportunity to improve their language skills.

It should be also noted that flipped learning may increase motivation, provide positive attitude, build self-confidence, and enhance the satisfaction of students in language learning (Ayon, 2017; Grimsley, 2015; Leis, 2018; Li \& Zhang, 2016; Oki, 2016; Rosen, et al., 2017; Roth, 2016; Suranakkharin, 2017; Wagner-Loera, 2018; Xie \& Fang, 2016; Zhang, 2015; Tohei, 2018). Recent studies investigating perceptions of students' concerning the use of flipped learning in the field of teaching English reveal that students have largely positive perceptions and satisfying learning experiences (Abdelshaheed, 2017; 
Adnan, 2017; Alsowat, 2016; Hsieh et al., 2017; Li, 2016; Roth, 2016; Yudintseva, 2016). In the same way, a group of researchers (Engin \& Donanci, 2016; Loucky, 2017b; Teng, 2018) hold the views that flipped learning motivates students and boosts their confidence in gaining skills of speaking and writing. One of the important factors determining students' success in flipped learning could be attributed to their taking responsibilities for their own learning (Ahmed, 2016; Ayon, 2017; Ekmekci, 2017; ElBassuony, 2016; Khadragy, 2016; Sung, 2015). Besides, flipped learning allows students to have control over when and where they could engage with the content in their learning process (Patterson, 2018). This also reinforces students' understanding, success, and confidence in the course of their language learning (Lee \& Wallace, 2018; Zainuddin, 2017). Furthermore, some researchers assert that flipped learning fosters students' use of diverse learning strategies, allowing them to rehearse materials several times before class, do a search on materials to learn, exercise time management, and polish their cognitive thinking skills (Alsowat, 2016; Li \& Zhang, 2016; Oki, 2016; Sun, 2017; Wagner-Loera, 2018; Zainuddin, 2017). In-class time with the given activities provides students with the opportunities for deep discussion, practice, and deep thinking (Wagner-Loera, 2018).

The review of studies concerning the effectiveness of flipped learning in the field of teaching EFL/ESL has shown that it helps students increase their engagement in language learning. Among other affordances of flipped learning environment, immediate feedback, collaboration opportunities, and meaningful learning are enunciated by some researchers (Abdelrahman et al., 2017; Afrilyasanti et al., 2016; Grimsley, 2015; Rosen et al., 2017; Yang, 2017; Yeo, 2018). Evidence from several cohort studies indicates that it not only enhances students' English language levels through video activities but also enables them to have immediate feedback (Amiryousefi, 2017; Choe \& Seong, 2016; Lee \& Wallace, 2018) and positive collaboration (Gasmi, 2016; Soliman, 2016; Sung, 2015). Additionally, implementing flipped learning facilitates meaningful language learning, allowing them to interact with language activities at their own pace and convenience (Wu et al., 2017; Zhang et al., 2016). Several studies examining the use of flipped learning in the field of teaching English have reached the conclusions that flipping language learning offers students the chance of adjusting their pace of language learning (Köroğlu \& Çakır, 2017; Lee, 2017; Tohei, 2018; Yang et al., 2017) in a more personalised manner (Li, 2016; Sung, 2015; Wagner-Loera, 2018). The findings from these studies suggest that while doing some activities with enjoyment in a more flexible learning environment, students could seize the opportunity to replay the videos and review the activities as many times as they need for their full understanding of the content (Brown, 2017; Danuri et al., 2017; Ekmeci, 2017; Loucky, 2017; Doman \& Webb, 2017; Hung, 2017; Jeong, 2017; Kang, 2015; Wagner-Loera, 2018).

Available evidence supports that the use of flipped learning could help students establish a good interaction with their peers in-class and out-of-class environments and develop their language skills and knowledge (Thaichay \& Sitthitikul, 2016; Teng, 2018; Wu et al., 2017; Zainuddin, 2017). The success and satisfaction with flipped language may be attributed to the interaction students develop out of class and in-class time with peers, thereby strengthening and deepening their understanding of the content (Karimi \& Hamzavi, 2017; Zainuddin, 2017; Zhang, 2015; Zhonggen \& Guifang, 2016). Researchers also ascertain that the teacher is inevitably transformed from a knowledge provider to a facilitator who is expected to guide students to apply knowledge to real-world settings (Adnan, 2017; Li \& Zhang, 2016; Sun, 2017; Teng, 2018; Zhang et al., 2016).

\subsection{Challenges of flipped learning}

The review study reveals some challenges about the implementation of flipped learning in the field of teaching EFL/ESL. 
Table 3. The challenges of flipped learning in teaching EFL/ESL

\begin{tabular}{lll}
\hline Challenges & f & Sample research \\
\hline Poor access to the Internet & 7 & Yang et al., 2017 \\
Excessive workload for students & 6 & Gasmi, 2016 \\
Material preparation is time-consuming & 5 & Han, 2015 \\
Creates workload for teachers & 3 & Abdelshaheed, 2017 \\
Requires adjustment period & 3 & Doman \& Webb, 2017 \\
\hline
\end{tabular}

One of the most raised issues is students' access to the flipped learning videos due to the limited availability of Internet connection. Researchers report that the limited access to Internet may impede the sound implementation of flipped learning in field of teaching EFL/ESL (Abdelshaheed, 2017; Afrilyasanti et al., 2016; Boyraz \& Ocak, 2017; Gasmi, 2016; Grimsley, 2015; Soliman, 2016; Yang et al., 2017). Similarly, students may have difficulties in reviewing the content and completing their work on time in flipped language learning process (Abdelshaheed, 2017; Afrilyasanti et al., 2016; Al-Harbi \& Alshumaimeri, 2016; Gasmi, 2016). Several studies report that although flipped learning activities are likely to entail a workload on students (Adnan, 2017; Afrilyasanti et al., 2016, 2017; Chen Hsieh et al., 2017; Gasmi, 2016; Yang et al., 2017), students express their satisfaction with flipped language learning since it makes the contribution to their better understanding of the content in that process (Gasmi, 2016). As for the workload of teachers voiced by researchers (Chen Hsieh et al., 2017; Han, 2015; Wagner-Loera, 2018) the process of preparing authentic materials from the target language and culture with proper extensive and intensive language inputs compels them to allocate a considerable amount of time (Abdelshaheed, 2017; Al-Harbi \& Al-Bargi, 2017; Han, 2015; Webb et al., 2014; Yang et al., 2017). A study, however, reports that some of the teachers express that implementation of flipped learning in teaching English is a good way to enhance students' learning albeit the length of preparation time of the activities (Webb et al., 2014). Another challenge vocalised by some researchers is that prior to implementing flipped learning, adjustment period for teachers' and students' acceptance of flipped learning is necessary (Doman \& Webb, 2017; Engin \& Donanci, 2016; Webb et al., 2014).

\section{Discussion}

This systematic review reveals that unlike traditional language teaching environment where the teacher delivers all the content and students are often times passive listeners to the lecture, the implementation of flipped learning in the field of teaching EFL/ESL has laid great emphasis on the improvement of language skills of students. (Horn, 2013; Zhu \& Zhu, 2013). Flipped learning has changed the responsibility of content learning from the teacher to students in the form of active learning which places much of the responsibility of learning on students (Nouri, 2016). These results agree well with the results of the current study. Shifting the responsibility for learning onto the shoulders and minds of students is widely welcomed by students with satisfaction, appreciation, and approval. In addition to this, flipped learning provides incentives for students to be active participant of their language learning. This argument is consistent with the findings of the studies (Fryer et al., 2014; Stockwell, 2010). The integration of technology into language learning has beneficial effects on students' motivation. The study of Fryer et al. (2014) claims that motivation is a strong indicator of students' success. Coupled with its offer of incentivising students to take part in language learning, flipped learning also enables students to exercise greater control of, and take greater responsibility for their own language learning, thereby gaining confidence in language learning beyond the classroom. Studies have demonstrated a 
strong and consistent link with the results of the current study (Fautch 2015; Häkkinen \& Hämäläinen, 2012; Lemmer, 2013).

Some researchers express some concern over the lack of student engagement in traditional language classrooms. (Kuh et al., 1997; Junior, 2015; Sheard et al., 2010). However, in the pedagogy of flipped learning, learning environment is transformed into a dynamic, collaborative, flexible, and interactive space where students are actively and deeply engaged with activities and content that may help them cultivate their cognitive capacities and competences through more meaningful interaction with other students and the teacher. This is consistent with the findings of the studies (Brame, 2013; Loyens et al., 2006; McCarthy, 2016; Pike et al., 2003; Tross et al., 2000) which suggest that students are initially exposed to new content out of the classroom and then assimilate that knowledge through engagement process. Engagement plays a crucial role for both deep learning, academic progress, and cultivation of cognitive capacities with thinking skills (Loyens et al., 2006; McCarthy, 2016; Pike et al., 2003; Tross et al., 2000).

With flipped language learning, transforming traditional language teaching into self-paced and directed learning allows the teacher being a guide on the side instead of sage on the stage to maximise guiding in-class time and provide more opportunities for individual teaching and feedback on students' language learning progress. This finding is supported by the researchers (Albó et al., 2017; Evseeva \& Solozhenko, 2015; Davies et al., 2013; Hamdan et al., 2013; Stutzmann et al., 2013) who assert that the teacher serves as a guide to accelerate students' potential for gaining competence in the course of their interaction with the content and activities in the target language.

The technological affordance of flipped learning is the content including video lectures and other materials. Flipped learning allows the content to be viewed at a pace under the control of students with the ability to review it anytime and anywhere (Cottrell \& Robison, 2003; Horn, 2013). In the same vein, Newman et al. (2015) note that unlimited access to the content such as videos is of great assistance to students in order to facilitate knowledge rehearsal and develop self-regulated learning. These studies have demonstrated the similar results in accordance with the present study.

Although numerous benefits are attributed to the use of flipped learning in the field of teaching EFL/ESL, there are some challenges including access to the Internet, workload for both teachers and students, time-consuming material preparation, and the adjustment for flipped learning. The finding about the challenge of Internet access is also reported by the researchers (Evseeva \& Solozhenko, 2015; Grimsley, 2015; Roach, 2013); however, according to Raths (2014) flipped learning is not difficult to be applied with limited internet access since the DVD can be used as an alternative tool for sharing the content including video activities with students.

Another challenge in the current study is the workload for teachers who are expected to find or prepare proper videos or resources for students. This also accords with the earlier studies (KarabulutIlgu et al., 2018; Lo \& Hew, 2017; McCarthy, 2016) which report that preparing flipped materials creates considerable workload for teachers. Similarly, as for the workload of students, research has consistently shown that students consider pre-class activities to be time-consuming and overwhelming (Snyder et al. 2014; Wang, 2016). The findings of the present study about the necessity of adjustment of students and teachers for flipped learning are in agreement with the findings of the studies (Kirvan et al., 2015; Zuber 2016) which posit that students and teacher need training prior to practicing flipped learning in order to put it into full use (Kirvan et al., 2015; Zuber 2016). 


\section{Conclusions}

Although flipped learning goes back to early-mid of 2000s (Bergmann \& Sams, 2012), it does not have a long history especially in the field of teaching EFL/ESL. This study set out to shed a light on the benefits and challenges of flipped learning in the field of teaching EFL/ESL. This review highlights the potential usefulness of flipping learning albeit some challenges in the field of teaching English. However, to the best of my knowledge, more longitudinal studies on the implementation of flipped learning in the field should be conducted.

Further studies focusing on finding solutions to reported challenges in the literature need to be carried out. In addition to this, further research should be undertaken to investigate students' learning styles, cognitive, and metacognitive strategies they use while they are attending a flipped language course.

As final remarks, flipped learning is potentially a stepping-stone to a better language teaching with a more enriched, innovative, flexible, learner-driven environment. Flipped learning is at its heart an act of promising pedagogy for teaching EFL/ESL better.

\section{Ethics Committee Approval}

The author(s) confirm(s) that the study does not need ethics committee approval according to the research integrity rules in their country. (Date of Confirmation: March 10, 2020)

\section{References}

Abeysekera, L., \& Dawson, P. (2015). Motivation and cognitive load in the flipped classroom: definition, rationale and a call for research. Higher Education Research \& Development, 34(1), 114.

Akçayır, M., \& Akçayır, G. (2017). Advantages and challenges associated with augmented reality for education: A systematic review of the literature. Educational Research Review, 20, 1-11.

Albó, L., Hernández-Leo, D., Barcelo, J., \& Sanabria-Russo, L. (2016). Video-based learning in higher education: the flipped or the hands-on classroom? European Journal of Open, Distance and Elearning, 19(2).

Amhag, L. (2017). Mobile technologies for student centred learning in a distance higher education program. In Information Resources Management Association (Ed.), Blended learning: Concepts, methodologies, tools, and applications (pp. 802-817). IGI Global.

Barrons, K. P. (2017). Flipped instructional technology: Developing MIS competencies applying enterprise resource planning. In Information Resources Management Association (Eds.), Blended learning: Concepts, methodologies, tools, and applications (pp. 702-712). IGI Global.

Berg, B. L., \& Lune, H. (2001). An introduction to content analysis. Qualitative research methods for the social sciences, 7, 238-267.

Bergmann, J., \& Sams, A. (2012). Before you flip, consider this. Phi Delta Kappan, 94(2), 25-25.

Booth, A., Sutton, A., \& Papaioannou, D. (2016). Systematic approaches to a successful literature review. Sage.

Brame, C. (2013). Flipping the classroom. Retrieved December 12, 2019, from http://cft.vanderbilt.edu/guides-sub-pages/flipping-theclassroom/ 
Brown, S. A. (2012). Seeing Web 2.0 in context: A study of academic perceptions. The Internet and Higher Education, 15(1), 50-57.

Burnard, P. (1991). A method of analysing interview transcripts in qualitative research. Nurse education today, 11(6), 461-466.

Catanzaro, M. (1988). Using qualitative analytical techniques. Nursing research: Theory and practice, 437-456.

Chellapan, L., \& van der Meer, J. (2017). Challenges in implementing the flipped classroom model in higher education. In J. Keengwe, \& G. Orchwari (Eds.), Handbook of research on active learning and the flipped classroom model in the digital age (pp. 352-365). IGI Global.

Chen, D. T. V., Wang, Y. M., \& Lee, W. C. (2016). Challenges confronting beginning researchers in conducting literature reviews. Studies in Continuing Education, 38(1), 47-60.

Cottrell, D. M., \& Robison, R. A. (2003). Case 4: Blended learning in an accounting course. Quarterly Review of Distance Education, 4(3), 261-69.

Coyle, V. C., Newman, D. L., \& Connor, K. A. (2016). Innovative instruction in STEM education: The role of student feedback in the development of a flipped classroom. In J. Keengwe, \& G. Orchwari (Eds.), Handbook of research on active learning and the flipped classroom model in the digital age (pp. 309-332). IGI Global.

Cresap, L. (2015). Preparing university students for flipped learning. In A. G. Scheg (Eds.), Implementation and critical assessment of the flipped classroom experience (pp. 175-195). IGI Global.

Davies, R. S., Dean, D. L., \& Ball, N. (2013). Flipping the classroom and instructional technology integration in a college-level information systems spreadsheet course. Educational Technology Research and Development, 61(4), 563-580.

Dennen, V. P., \& Spector, J. M. (2017). The flipped K-12 classroom: Implications for teacher preparation, professional development, and educational leadership. In M. D. Avgerinou, \& S. P. Gialamas (Eds.), Revolutionizing K-12 blended learning through the $i^{2}$ Flex classroom model (pp. 38-51). IGI Global.

Diaz, V., \& Brown, M. (2010). Blended learning: A report on the ELI focus session. EDUCAUSE learning initiative.

Downe-Wamboldt, B. (1992). Content analysis: method, applications, and issues. Health care for women international, 13(3), 313-321.

Evseeva, A., \& Solozhenko, A. (2015). Use of flipped classroom technology in language learning. Procedia-Social and Behavioral Sciences, 206, 205-209.

Faulkner, T., \& Green, J. (2017). The peer instruction flipped learning model. In Information Resources Management Association (Ed.), Blended learning: Concepts, methodologies, tools, and applications (pp. 285-307). IGI Global.

Fautch, J. M. (2015). The flipped classroom for teaching organic chemistry in small classes: Is it effective? Chemistry Education Research and Practice, 16(1), 179-186.

Fryer, L. K., Ginns, P., \& Walker, R. (2014). Between students' instrumental goals and how they learn: Goal content is the gap to mind. British Journal of Educational Psychology, 84(4), 612-630. 
Galvez, H. (2017). Flipped instruction for language learning. In Flipped instruction methods and digital technologies in the language learning classroom (pp. 91-107). IGI Global.

Gash, S. (2000). Effective literature searching for research. Gower.

Gough, D., Oliver, S., \& Thomas, J. (2017). An introduction to systematic reviews. Sage.

Graneheim, U. H., \& Lundman, B. (2004). Qualitative content analysis in nursing research: concepts, procedures and measures to achieve trustworthiness. Nurse education today, 24(2), 105-112.

Grayson, L., \& Gomersall, A. (2003). A difficult business: finding the evidence for social science reviews. London: ESRC UK Centre for Evidence Based Policy and Practice, Queen Mary University of London.

Grewal, A., Kataria, H., \& Dhawan, I. (2016). Literature search for research planning and identification of research problem. Indian journal of anaesthesia, 60(9), 635.

Häkkinen, P., \& Hämäläinen, R. (2012). Shared and personal learning spaces: Challenges for pedagogical design. The Internet and Higher Education, 15(4), 231-236.

Hamdan, N., McKnight, P. E., McKnight, K., \& Arfstrom, K. M. (2013). A review of flipped learning. Retrieved November 15, 2019, from http://www.flippedlearning.org/review/.

Hart, C. (1998). Doing a literature review: Releasing the social science research imagination. Sage.

Hartling, L., Featherstone, R., Nuspl, M., Shave, K., Dryden, D. M., \& Vandermeer, B. (2017). Grey literature in systematic reviews: a cross-sectional study of the contribution of non-English reports, unpublished studies and dissertations to the results of meta-analyses in child-relevant reviews. BMC medical research methodology, 17(1), 64.

Horn, M. B. (2013). The transformational potential of flipped classrooms. Education Next, 13(3), 7879.

Junior, J. C. K. (2015). Analysing the effectiveness of engagement-promoting techniques in the EFL classroom. International Journal of Learning, Teaching and Educational Research, 10(1).

Katz, A., Brown, T. M., \& Kim, J. H. Y. (2017). A professional development framework for the flipped classroom model: Design and implementation of a literacy and math integrated professional development initiative. In J. Keengwe, \& G. Orchwari (Eds.), Handbook of research on active learning and the flipped classroom model in the digital age (pp. 122-149). IGI Global.

Kim, M. K., Kim, S. M., Khera, O., \& Getman, J. (2014). The experience of three flipped classrooms in an urban university: An exploration of design principles. The Internet and Higher Education, 22, 3750 .

Kirvan, R., Rakes, C. R., \& Zamora, R. (2015). Flipping an algebra classroom: analyzing, modeling, and solving systems of linear equations. Computers in the Schools, 32(3-4), 201-223.

Krippendorff, K. (2004). Content analysis: an introduction to its methodology. Thousand Oaks, California: Sage Publications Inc.

Kuh, G. D., Hu, S., \& Vesper, N. (2000). "They shall be known by what they do": An activities-based typology of college students. Journal of College Student Development, 41, 228-244.

LaFee, S. (2013). Flipped learning. The Education Digest, 79(3), 13-18. 
Leis, A. (2018). Content-Based Language Teaching and the Flipped Classroom: A Case Study in the Japanese EFL Environment. In Innovations in Flipping the Language Classroom (pp. 221-230). Springer, Singapore.

Lemmer, C. (2013). A view from the flip side: using the "inverted classroom" to enhance the legal information literacy of the international LL.M. student. Law Library Journal, 105(4), 461-491.

Littell, J. H., Corcoran, J., \& Pillai, V. (2008). Systematic reviews and meta-analysis. Oxford University Press.

Loucky, J. P. (2017a). Motivating and Empowering Students' Language Learning in Flipped Integrated English Classes. In Flipped Instruction Methods and Digital Technologies in the Language Learning Classroom (pp. 108-138). IGI Global

Loyens, S. M., Rikers, R. M., \& Schmidt, H. G. (2006). Students' conceptions of constructivist learning: a comparison between a traditional and a problem-based learning curriculum. Advances in Health Sciences Education, 11(4), 365-379.

Madden, M., Lenhart, A., Cortesi, S., Gasser, U., Duggan, M., Smith, A., \& Beaton, M. (2013). Teens, social media, and privacy. Pew Research Center, 21, 2-86.

McAuley, L., Tugwell, P., \& Moher, D. (2000). Does the inclusion of grey literature influence estimates of intervention effectiveness reported in meta-analyses?. The Lancet, 356(9237), 1228-1231.

McCarthy, J. (2016). Reflections on a flipped classroom in first year higher education. Issues in Educational Research, 26(2), 332.

Missildine, K., Fountain, R., Summers, L., \& Gosselin, K. (2013). Flipping the classroom to improve student performance and satisfaction. Journal of Nursing Education, 52(10), 597-599.

Moher, D., Liberati, A., Tetzlaff, J., \& Altman, D. G. (2010). Preferred reporting items for systematic reviews and meta-analyses: the PRISMA statement. Int J Surg, 8(5), 336-341.

Moran, C. M., Young, C. A., Brooks, N., \& Romano, A. (2017). Flipping the Flip to Empower Students: Using Constructivist Principles to Reinvent Flipped ELA Instruction. In Applying the Flipped Classroom Model to English Language Arts Education (pp. 229-254). IGI Global.

Newman, D. L., Deyoe, M. M., Connor, K. A., \& Lamendola, J. M. (2015). Flipping STEM learning: Impact on students' process of learning and faculty instructional activities. In Curriculum design and classroom management: Concepts, methodologies, tools, and applications (pp. 23-41). IGI Global.

Nielsen, L. (2012). Five reasons I'm not flipping over the flipped classroom. Technology \& Learning, $32(10), 46-46$.

Nouri, J. (2016). The flipped classroom: for active, effective and increased learning-especially for low achievers. International Journal of Educational Technology in Higher Education, 13(1), 33.

O'Flaherty, J., \& Phillips, C. (2015). The use of flipped classrooms in higher education: A scoping review. The Internet and Higher Education, 25, 85-95.

Ogden, L., \& Shambaugh, N. (2016). The continuous and systematic study of the college algebra flipped classroom. In Handbook of research on active learning and the flipped classroom model in the digital age, 41-71. IGI Global

Parslow, G. R. (2012). Commentary: The Khan academy and the day-night flipped classroom. Biochemistry and Molecular Biology Education, 40(5), 337-338. 
Perkins, D. (2006). Constructivism and troublesome knowledge In JHF Meyer \& R. Land (Eds.) Overcoming barriers to student understanding: Threshold concepts and troublesome knowledge (pp. $33-47)$.

Petticrew, M., \& Roberts, H. (2006). How to appraise the studies: an introduction to assessing study quality. Systematic reviews in the social sciences: A practical guide, 125-163.

Picciano, A. G., Dziuban, C. D., \& Graham, C. R. (Eds.). (2013). Blended learning: Research perspectives (Vol. 2). Routledge.

Pike, G. R., Kuh, G. D., \& Gonyea, R. M. (2003). The relationship between institutional mission and students' involvement and educational outcomes. Research in Higher Education, 44(2), 241-261.

Plaisent, M., Dayagbil, F., Pogoy, A. M., \& Bernard, P. (2017). Is Flipped classroom a tendency or a fad?: The point of view of future teachers in the Philippines. In Information Resources Management Association (Ed.), Blended learning: Concepts, methodologies, tools, and applications (pp. 21502168). IGI Global.

Prodoehl, D. E. (2015). Flipping first-year English: Strengthening teacher-student conferencing through online modules. In A. G. Scheg (Ed.), Implementation and critical assessment of the flipped classroom experience (pp. 1-24). IGI Global.

Raths, D. (2014). Nine video tips for a better flipped classroom. The Education Digest, 79(6), 15.

Rideout, V. J., Foehr, U. G., \& Roberts, D. F. (2010). Generation M 2: Media in the Lives of 8-to 18Year-Olds. Henry J. Kaiser Family Foundation.

Ridley, D. (2012). The literature review: A step-by-step guide for students. Sage.

Roach, T. (2013). The Friday flip: New methods to increase interaction and active learning $\begin{array}{llll}\text { economics. Retrieved January } & 10, & \text { 2019, }\end{array}$ https://papers.ssrn.com/sol3/papers.cfm?abstract_id=2302898

Roberts, N. A., \& Plakhotnik, M. S. (2009). Building social capital in the academy: The nature and function of support systems in graduate adult education. New directions for adult and continuing education, 2009(122), 43-52.

Rosen, L. B., Maeda, M., \& Roberts, N. (2017). Gain time and differentiate to meet student needs in university learning environments: A flipped learning approach. In Flipped Instruction: Breakthroughs in Research and Practice (pp. 215-232): IGI Global.

Ross, C. (2011). Today's wired classroom. Electrical Contractor. Retrieved November 13, 2019, from http://www.ecmag.com/section/your-business/todays-wired-classrooms/.

Rousseau, D. M., Manning, J., \& Denyer, D. (2008). 11 Evidence in management and organizational science: assembling the field's full weight of scientific knowledge through syntheses. The academy of management annals, 2(1), 475-515.

Russell, V. (2012). Learning complex grammar in the virtual classroom: A comparison of processing instruction, structured input, computerized visual input enhancement, and traditional instruction. Foreign Language Annals, 45(1), 42-71.

Salifu, S. (2016). Understanding flipped instructions and how they work in the real world. In Information Resources Management Association (Ed.), Blended learning: Concepts, methodologies, tools, and applications (pp. 1970-1988). IGI Global.

Sams, A., \& Bergmann, J. (2013). Flip your students' learning. Educational leadership, 70(6), 16-20. 
Shaffer, S. (2017). Examining the potential for flipped literature units: Flipping the Great Gatsby. In $C$. A. Young, \& C. M. Moran (Eds.), Applying the flipped classroom model to English language arts education (pp. 1-32). IGI Global.

Sheard, J., Carbone, A., \& Hurst, A. J. (2010). Student engagement in first year of an ICT degree: Staff and student perceptions. Computer Science Education, 20(1), 1-16. doi:10.1080/08993400903484396

Snyder, C., Paska, L. M., \& Besozzi, D. (2014). Cast from the past: using screen casting in the social studies classroom. The Social Studies, 105(6), 310-314.

Snyder, N. C. (2017). Teachers' perceived advantages and disadvantages of using flipped classrooms in ELA and non-ELA classrooms. In C. A. Young, \& C. M. Moran (Eds.), Applying the flipped classroom model to English language arts education (pp. 59-78). IGI Global.

Stockwell, G. (2010). Using mobile phones for vocabulary activities: Examining the effect of the platform. Language Learning \& Technology, 14(2), 95-110. Retrieved June 12, 2019, from http://llt.msu.edu/vol14num2/stockwell.pdf

Strayer, J. F. (2012). How learning in an inverted classroom influences cooperation, innovation and task orientation. Learning environments research, 15(2), 171-193.

Stutzmann, B., Colebech, D., Khalid, A., Chin, C., \& Sweigart, J. (2013). Flipped Classroom or Flipped Out?: Professors Attitudes Towards Online Learning.

Taylor, B. J., Dempster, M., \& Donnelly, M. (2003). Hidden gems: Systematically searching electronic databases for research publications for social work and social care. British Journal of Social Work, 33(4), 423-439.

Trogden, B. G. (2017). The view from a flipped classroom: Improved student success and subject mastery in organic chemistry. In Information Resources Management Association (Ed.), Blended learning: Concepts, methodologies, tools, and applications (pp. 327-345). IGI Global.

Tross, S. A., Harper, J. P., Osher, L. W., \& Kneidinger, L. M. (2000). Not just the usual cast of characteristics: Using personality to predict college performance and retention. Journal of College Student Development.

Umezawa, K., Ishida, T., Aramoto, M., Kobayashi, M., Nakazawa, M., \& Hirasawa, S. (2017). A method based on self-study log information for improving effectiveness of classroom component in flipped classroom approach. In Information Resources Management Association (Ed.), Blended learning: Concepts, methodologies, tools, and applications (pp. 1818-1834). IGI Global.

Wang, Y. H. (2016). Could a mobile-assisted learning system support flipped classrooms for classical Chinese learning? Journal of Computer Assisted Learning, 32, 391-415.

Wells, M., \& Holland, C. (2017). Flipping learning!: Challenges in deploying online resources to flipped learning in higher education. In Information Resources Management Association (Ed.), Blended learning: Concepts, methodologies, tools, and applications (pp. 29-47). IGI Global.

Xiao, Y., \& Watson, M. (2019). Guidance on conducting a systematic literature review. Journal of Planning Education and Research, 39(1), 93-112.

Xin-yue, Z. U. O. (2016). Motivation in a flipped classroom, a case study of teaching oral English in a vocational college in Mainland China. Sino-US English Teaching, 13(6), 460-467. 
Yang, C. C. R. (2017). An investigation of the use of the 'flipped classroom' pedagogy in secondary English language classrooms. Journal of Information Technology Education: Innovations in Practice, 16(1).

Yang, L., Sun, T., \& Liu, Y. (2017). A bibliometric investigation of flipped classroom research during 2000-2015. International Journal of Emerging Technologies in Learning (iJET), 12(06), 178-186.

Yarbro, J., Arfstrom, K. M., McKnight, K., \& McKnight, P. (2014). Extension of a review of flipped learning. Retrieved on June, 2, 2019, from https://flippedlearning.org/wpcontent/uploads/2016/07/Extension-of-FLipped-Learning-LIt-Review-June-2014.pdf/.

Young, K., Ashby, D., Boaz, A., \& Grayson, L. (2002). Social science and the evidence-based policy movement. Social policy and society, 1(3), 215-224.

Zhang, H., Li, J., Jiao, L., Ma, W., \& Guan, C., H., Du, X., Yuan, X., \& Zhang, L. (2016). The effectiveness of the flipped classroom mode on the English pronunciation course. Creative Education, 7(09), 1340.

Zuber, W. J. (2016). The flipped classroom, a review of the literature. Industrial and Commercial Training, 48(2), 97-103.

\section{Appendix A. The list of reviewed studies}

Abaeian, H., \& Samadi, L. (2016). The effect of flipped classroom on Iranian EFL learners' L2 reading comprehension: Focusing on different proficiency levels. Reading Comprehension, 3(6), 10.

Abdelrahman, L. A. M., DeWitt, D., Alias, N., \& Rahman, M. N. A. (2017). Flipped learning for ESL writing in a Sudanese school. The Turkish Online Journal of Educational Technology, 16(3), 12.

Abdelshaheed, B. S. M. (2017). Using flipped learning model in teaching English language among female English majors in Majmaah University. English Language Teaching, 10(11), 96. https://doi.org/10.5539/elt.v10n11p96

Adnan, M. (2017). Perceptions of senior-year ELT students for flipped classroom: A materials development course. $\quad$ Computer Assisted Language Learning, 30(3-4), 204-222. https://doi.org/10.1080/09588221.2017.1301958

Afrilyasanti, R., Cahyono, B. Y., \& Astuti, U. P. (2016). Effect of flipped classroom model on Indonesian EFL students' writing ability across and individual differences in learning. International Journal of English Language and Linguistics Research, 4(5), 65-81.

Afrilyasanti, R., Cahyono, B. Y., \& Astuti, U. P. (2017). Indonesian EFL students' perceptions on the implementation of flipped classroom model. Journal of Language Teaching and Research, 8(3), 476. https://doi.org/10.17507/jltr.0803.05

Ahmad, S. Z. (2016). The flipped classroom model to develop Egyptian EFL students' listening comprehension. English Language Teaching, 9(9), 166. https://doi.org/10.5539/elt.v9n9p166

Al-Fahid, M. F. (2017). Disruptive Practice in Saudi EFL Student Teachers' Learning to Teach through Flipped Classroom and Rehearsal: A Grounded Theory Study, (Doctoral dissertation, College of Education, The Pennsylvania State University, USA)

Al-Ghamdi, M., \& Al-Bargi, A. (2017). Exploring the application of flipped classrooms on EFL Saudi students' speaking skill. International Journal of Linguistics, 9(4), 28. https://doi.org/10.5296/ijl.v9i4.11729

Al-Harbi, S. S., \& Alshumaimeri, Y. A. (2016). The flipped classroom impact in grammar class on EFL Saudi secondary school students' performances and attitudes. English Language Teaching, 9(10), 60. https://doi.org/10.5539/elt.v9n10p60

Alsowat, H. (2016). An EFL flipped classroom teaching model: Effects on English language higher-order thinking skills, student engagement and satisfaction. Journal of Education and Practice, 7(9), 14.

Amiryousefi, M. (2017). The incorporation of flipped learning into conventional classes to enhance EFL learners' L2 speaking, L2 listening, and engagement. Innovation in Language Learning and Teaching, 13(2), 147 161. https://doi.org/10.1080/17501229.2017.1394307

Ayon, N. S. (2017). Flipped Learning: The Case of Professional English Writing Course. In 2017 The IAFOR International Conference on Language Learning-Dubai Official Conference Proceedings. The IAFOR International Conference on Language Learning, Dubai. 
Bajurny, A. (2014). An Investigation into The Effects of Flip Teaching on Student Learning, (Master thesis, University of Toronto, Canada)

Basal, A. (2015). The implementation of a flipped classroom in foreign language teaching. Turkish Online Journal of Distance Education, 16(4), 28-37.

Boyraz, S., \& Ocak, G. (2017). Implementation of flipped education into Turkish EFL teaching context. Journal of Language and Linguistic Studies, 13 (2), 426-439.

Brown, C. J. (2018). Flipping the ESL/EFL Academic Reading Classroom: A Group Leader Discussion Activity. In J. Mehring \& A. Leis (Eds.), Innovations in Flipping the Language Classroom (pp. 147-168). Springer Singapore. https://doi.org/10.1007/978-981-10-6968-0_11

Brown, D. (2017). Flipping the High School English Classroom Without Flipping Out: Maximizing Tech to Make Space for Text. In Applying the Flipped Classroom Model to English Language Arts Education (pp. 111128). IGI Global.

Buitrago, C. R., \& Díaz, J. (2018). Flipping Your Writing Lessons: Optimizing Time in Your EFL Writing Classroom. In J. Mehring \& A. Leis (Eds.), Innovations in Flipping the Language Classroom (pp. 6991). Springer Singapore. https://doi.org/10.1007/978-981-10-6968-0_6

Çelebi, H., Karaaslan, H., \& Demir-Vegter, S. (2016). The title of your paper: Corpus use in enhancing lexicogrammatical awareness through flipped applications. Journal of Language and Linguistic Studies, 12(2), 152-165.

Chen Hsieh, J. S., Wu, W.-C. V., \& Marek, M. W. (2017). Using the flipped classroom to enhance EFL learning. Computer Assisted Language Learning, 30(1-2), 1-21. https://doi.org/10.1080/09588221.2015.1111910

Cheung Ruby Yang, C. (2017). An Investigation of the Use of the 'Flipped Classroom' Pedagogy in Secondary English Language Classrooms. Journal of Information Technology Education: Innovations in Practice, 16, 001-020. https://doi.org/10.28945/3635

Choe, E., \& Seong, M. H. (2016). A Case Study of the Flipped Classroom in a Korean University General English Course. Journal of Pan-Pacific Association of Applied Linguistics, 20(2), 71-93.

Chuang, H.-H., Weng, C.-Y., \& Chen, C.-H. (2018). Which students benefit most from a flipped classroom approach to language learning?: Flipped classroom does not fit all students. British Journal of Educational Technology, 49(1), 56-68. https://doi.org/10.1111/bjet.12530

Doman, E., \& Webb, M. (2017). The Flipped Experience for Chinese University Students Studying English as a Foreign Language. TESOL Journal, 8(1), 102-141. https://doi.org/10.1002/tesj.264

Egbert, J., Herman, D., \& Lee, H. (2015). Flipped instruction in English language teacher education: A designbased study in a complex, open-ended learning environment. Tesl-Ej, 19(2).

Ekmekci, E. (2017). The flipped writing classroom in Turkish EFL context: A comparative study on a new model. Turkish Online Journal of Distance Education, 18(2), 151-151. https://doi.org/10.17718/tojde.306566

El-Bassuony, D. J. M. (2016). The Effectiveness of Flipped Learning in Developing English Grammatical Performance of Underachieving Language Learners at the Secondary Stage. International Journal of English Language Teaching, 4(8), 27.

Engin, M., \& Donanci, S. (2016). Instructional videos as part of a 'flipped' approach in academic writing. Learning and Teaching in Higher Education: Gulf Perspectives, 13(1). https://doi.org/10.18538/lthe.v13.n1.231

Gasmi, A. A. (2016). An Exploratory Study of Students' Lived Experiences in a Blended-Flipped Writing Class. Arab World English Journal, 3, 210-226.

Gasmi, A. A., \& Thomas, M. (2017). Academic writing in the flipped EFL classroom: A case study on student engagement in Oman. In Flipped instruction methods and digital technologies in the language learning classroom (pp. 232-251). IGI Global.

Ginola, D., \& Sidabalok, D. M. (2016, May). The Implementation of Flipped Classroom by Using Schoology in Speaking II Class of English Education Study Program of Teacher Training and Education Faculty of Bandar Lampung University. In International Conference on Education and Language (ICEL) (p. 199).

Grimsley, C. R. (2015). How students in a first-year composition course respond to the flipped classroom. In Implementation and critical assessment of the flipped classroom experience (pp. 99-118). IGI Global.

Han, Y. J. (2015). Successfully flipping the ESL classroom for learner autonomy. NYS Tesol Journal, 2(1), 98109.

Hung, H.-T. (2015). Flipping the classroom for English language learners to foster active learning. Computer Assisted Language Learning, 28(1), 81-96. https://doi.org/10.1080/09588221.2014.96770

Hung, H.-T. (2017). Design-Based Research: Redesign of an English Language Course Using a Flipped Classroom Approach. TESOL Quarterly, 51(1), 180-192. https://doi.org/10.1002/tesq.328

Iyitoğlu, O., \& Erişen, Y. (2017). Delving into flipping EFL classroom: A mixed method study. European Journal of English Language Teaching.

Jeong, K.-O. (2017). The use of Moodle to enrich flipped learning for English as a foreign language education. Journal of Theoretical \& Applied Information Technology, 95(18) 
Kang, Namhee. (2015). The Comparison between Regular and Flipped Classrooms for EFL Korean Adult Learners. Multimedia-Assisted Language Learning, 18(3), 41-72. https://doi.org/10.15702/mall.2015.18.3.41

Karimi, M., \& Hamzavi, R. (2017). The Effect of Flipped Model of Instruction on EFL Learners' Reading Comprehension: Learners' Attitudes in Focus. Advances in Language and Literary Studies, 8(1), 95. https://doi.org/10.7575/aiac.alls.v.8n.1p.95

Khadragy, S. A. M. (2016). The Impact of the Flipped Classroom Model of Instruction on the Reading Achievement of Ninth Grade Female Emirati students in the Qurtoba Public School in Dubai. The British University in Dubai (BUiD), Dubai.

Kirk, S., \& Casenove, D. (2017). Flipping the Academic Writing Classroom. In Flipped Instruction Methods and Digital Technologies in the Language Learning Classroom (pp. 196-231). IGI Global.

Köroğlu, Z. Ç., \& Çakır, A. (2017). Implementation of flipped instruction in language classrooms: An alternative way to develop speaking skills of pre-service English language teachers. International Journal of Education and Development using Information and Communication Technology (IJEDICT), 13 (2), pp. 42-55.

Lee, G., \& Wallace, A. (2018). Flipped Learning in the English as a Foreign Language Classroom: Outcomes and Perceptions. TESOL Quarterly, 52(1), 62-84. https://doi.org/10.1002/tesq.372

Lee, Y. J. (2017). Using Web-Based Tools for Flipped ESL Learning in the Korean Language Education System. In Computer-Assisted Language Learning: Concepts, Methodologies, Tools, and Applications (pp. 1203 1217). IGI Global.

Li, H., \& Zhang, Y. (2016). Application of Flipped Classroom in Medical Oral English Teaching. In 2016 Eighth International Conference on Measuring Technology and Mechatronics Automation (ICMTMA), 105-108. https://doi.org/10.1109/ICMTMA.2016.34

Li, S. (2015). Enhancing EFL speaking via flipped classroom model and constructive role plays (Doctoral dissertation, School of Foreign Languages. Institute of Social Technology. Suranaree University of Technology).

Li, S. (2016). A Study of Learners' Satisfaction towards College Oral English Flipped Classroom. Theory and Practice in Language Studies, 6(10), 1958. https://doi.org/10.17507/tpls.0610.10

Loucky, J. P. (2017b). Studies of flipping classes with Asian students. In Flipped Instruction: Breakthroughs in Research and Practice (pp. 168-188). IGI Global.

Mehring, J. G. (2015). An exploratory study of the lived experiences of Japanese undergraduate EFL students in the flipped classroom. (Doctoral dissertation, Pepperdine University, California, USA).

Mervat Abd Elfatah Ali Said Ahmed. (2016). The Effect of a Flipping Classroom on Writing Skill in English as a Foreign Language and Students' Attitude Towards Flipping. US-China Foreign Language, 14(2), 98114. https://doi.org/10.17265/1539-8080/2016.02.003

Norazmi, D., Dwee, C. Y., Suzilla, J., \& Nurzarina, A. S. (2017). Exploring student engagement in writing using the flipped classroom approach. Pertanika Journal of Social Science and Humanities, 25(2), 663-674.

Oki, Y. (2016). Flipping a Content-Based ESL Course: An Action Research Report. 14, 62-75.

Patterson, D. (2018). The Flipped EFL Classroom: A Teaching Approach for the Information Age. In 2018 Thailand TESOL International Conference Proceedings.

Rama, R. (2018). Collaborative Language Learning in Higher Education: Student Engagement and Language Self-Efficacy in a Communicative, Flipped Context (Doctoral dissertation, Arizona State University).

Ramirez, M. (2018). Flipping a Pronunciation Lesson for a Teacher Training Course. In J. Mehring \& A. Leis (Eds.), Innovations in Flipping the Language Classroom (pp. 45-57). Springer Singapore. https://doi.org/10.1007/978-981-10-6968-0_4

Roth, C. (2016). Flipped classroom: Can it enhance English listening comprehension for pre-university student in Cambodia? In 2016 CLS International Conference CLaSIC, 10.

Santikarn, B., \& Wichadee, S. (2018). Flipping the Classroom for English Language Learners: A Study of Learning Performance and Perceptions. International Journal of Emerging Technologies in Learning (IJET), 13(09), 123. https://doi.org/10.3991/ijet.v13i09.7792

Soliman, N. A. (2016). Teaching English for academic purposes via the flipped learning approach. ProcediaSocial and Behavioral Sciences, 232, 122-129.

Sun, Y. C. (2017). Flipping every student? A case study of content-based flipped language classrooms. E-Learning and Digital Media, 14(1-2), 20-37. https://doi.org/10.1177/2042753017692428

Sung, K. (2015). A Case Study on a Flipped Classroom in an EFL Content Course. Multimedia-Assisted Language Learning, 18(2), 159-187. https://doi.org/10.15702/mall.2015.18.2.159

Suranakkharin, T. (2017). Using the Flipped Model to Foster Thai Learners' Second Language Collocation Knowledge. 3L The Southeast Asian Journal of English Language Studies, 23(3), 1-20. https://doi.org/10.17576/3L-2017-2303-01 
Teng, M. F. (2018). Flip Your Classroom to Improve EFL Students' Speaking Skills. In J. Mehring \& A. Leis (Eds.), Innovations in Flipping the Language Classroom (pp. 113-122). Springer Singapore. https://doi.org/10.1007/978-981-10-6968-0_9

Thaichay, T., \& Sitthitikul, P. (2016). Effects of the flipped classroom instruction on language accuracy and learning environment: A case study of Thai EFL upper-secondary school students. Rangsit Journal of Educational Studies, 3(2), 35-64.

Wagner-Loera, D. (2018). Flipping the ESL/EFL Classroom to Reduce Cognitive Load: A New Way of Organizing Your Classroom. In J. Mehring \& A. Leis (Eds.), Innovations in Flipping the Language Classroom (pp. 169-184). Springer Singapore. https://doi.org/10.1007/978-981-10-6968-0_12

Webb, M., \& Doman, E. (2016). Does the Flipped Classroom Lead to Increased Gains on Learning Outcomes in ESL/EFL Contexts? CATESOL Journal, 28(1), 39-67.

Webb, M., Doman, E., \& Pusey, K. (2014). Flipping a Chinese University EFL Course: What Students and Teachers Think of the Model. The Journal of Asia TEFL, 35.

Wu, W. C. V., Hsieh, J. S. C., \& Yang, J. C. (2017). Creating an online learning community in a flipped classroom to enhance EFL learners' oral proficiency. Journal of Educational Technology \& Society, 20(2), 142-157.

Xie, X., \& Fang, Q. (2016). A Study of Flipped Classroom's Influence on Classroom Environment of College English Reading, Writing and Translating. In 2016 Proceedings 4th International Conference on Management, Education, Information and Control (MEICI 2016). 2016 4th International Conference on Management, Education, Information and Control (MEICI 2016), Shenyang, China. https://doi.org/10.2991/meici-16.2016.65

Yeo, M. (2018). Flipping or Flopping: Lessons Learnt from Flipping a Course for ASEAN Teachers of English. In J. Mehring \& A. Leis (Eds.), Innovations in Flipping the Language Classroom (pp. 23-44). Springer Singapore. https://doi.org/10.1007/978-981-10-6968-0_3

Yu, Z., \& Zhu, Q. (2016, July). Comparison of Satisfaction in EFL Flipped and Traditional Classrooms. In 2016 2nd International Conference on Humanities and Social Science Research (ICHSSR 2016). Atlantis Press.

Yudintseva, A. (2016). Flipped Model of Instruction in English as a second language classroom: A Kazakhstani perspective. In 2016 Proceedings of INTED2016 Conference 7th-9th March, Valencia, Spain.

Zainuddin, Z. (2017). First-Year College Students' Experiences in the EFL Flipped Classroom: A Case Study in Indonesia. International Journal of Instruction, 10(1), 133-150.

Zaki, A. T. (2017). A Developmental Study of the Flipped Classroom Approach on Students' Learning in English Language Modules in British University in Egypt. 11(8), 7.

Zhang, H., Li, J., Jiao, L., Ma, W., \& Guan, C. (2016). The Adjustment and Effects of Vocabulary Teaching Strategies in Flipped Classroom. Creative Education, 07(14), 1966-1973. https://doi.org/10.4236/ce.2016.714199

Zhang, L. (2015). Teaching Model design of Business English based on flipped classroom case study. Proceedings of the 2015 International Conference on Education, Management and Computing Technology. International Conference on Education, Management and Computing Technology (ICEMCT-15), Tianjin, China. https://doi.org/10.2991/icemct-15.2015.37

Zhonggen, Y. (2018). Video lecturing in Clicker-assisted English flipped class. PLOS ONE, 14(10), e0224209. https://doi.org/10.1371/journal.pone.0224209

Zhonggen, Y., \& Guifang, W. (2016). Academic Achievements and Satisfaction of the Clicker-Aided Flipped Business English Writing Class. Journal of Educational Technology \& Society, 19(2). 


\section{Yabancı veya ikinci dil olarak İngilizce öğretiminde kullanılan tersyüz edilmiş öğrenme yaklaşımı üzerine sistematik bir derleme}

\section{$\ddot{O ̈ z}$}

$\mathrm{Bu}$ çalışmanın amacı sistematik derleme yoluyla tersyüz edilmiş öğrenme yaklaşımının İngilizce'nin yabancı veya ikinci dil olarak öğretiminde kullanımı sürecindeki faydalarını ve zorluklarını irdelemektir. Bu kapsamda Web of Science (WOS), ERIC, ScienceDirect, SCOPUS, IGI Global ve Wiley Online Library veritabanları taranmıştır. Veri tabanlarından elde edilen çalışmaların araştırmacı tarafından belirlenen bir dizi ölçütler çerçevesinde incelenmesinden sonra nihai olarak 78 çalışmanın bu derleme çalışmasına dahil edilmesi uygun bulunmuştur. Yapılan içerik analizi bağlamında kodlara ve temalara ulaşılmıştır. İngilizce'nin yabancı veya ikinci dil olarak öğretiminde terzyüz edilmiş öğrenme yaklaşımına dair çalışmaların örnekleminin çoğunluğunun üniversite öğrencilerinden oluştuğu görülmektedir. Terzyüz edilmiş öğrenme yaklaşımının yazma ve konuşma gibi dil becerilerinin gelişimi üzerinde olumlu etkileri olduğu görülmektedir. Ancak derleme kapsamında bazı çalı̧̧malardan elde edilen sonuçlar hem öğrenciler hem de öğretmenler için internet erişimi, iş yükü gibi bazı konularda zorlukların olduğunu ortaya koymaktadır.

Anahtar sözcükler: İngilizce öğretimi; tersyüz edilmiş öğrenme; dil becerileri; dil öğrenimi; içerik analizi

\section{AUTHOR BIODATA}

Abdullah Arslan is currently an Assistant Professor at Shanghai International Studies University, Shanghai, China. His research interests include blended learning, teacher education, the CEFR, teaching skills, and curriculum design. 